\title{
Influence of Drip Irrigation Regimes and Lateral Spacing on Cumin Productivity
}

\author{
ARVIND N. KUNAPARA*, R. SUBBAIAH, GIRISH V. PRAJAPATI and JAYDIP J. MAKWANA \\ Centre of Excellence on Soil and Water Management, \\ RTTC, Junagadh Agricultural University, Junagadh, Gujarat, India.
}

http://dx.doi.org/10.12944/CWE.11.1.40

(Received: January 07, 2016; Accepted: February 13, 2016)

\begin{abstract}
Cumin is one of the important spice crops grown in arid and semi arid regions of India and is being adopted to cure some of the dreaded diseases. Determination of optimum water requirement which is function of soil crop and atmosphere is needed for achieving more profit and higher productivity per unit of water. Keeping in view, a field experiment was undertaken to access the conjugate impact of three irrigation regimes $\left(0.6 \mathrm{IW} / \mathrm{ET}_{c}, 0.8 \mathrm{IW} / \mathrm{ET}_{c}\right.$ and1.0IW/ET $\left.{ }_{c}\right)$ and three lateral spacing $(0.60 \mathrm{~m}, 0.70 \mathrm{~m}$ and $0.80 \mathrm{~m})$ on productivity of cumin. Split plot design with three treatment replications was adopted. Drip irrigation with $0.8 \mathrm{IW} / \mathrm{ET}_{\mathrm{c}}$ resulted higher seed yield, plant height and dry matter of $1344.17 \mathrm{~kg} / \mathrm{ha}, 36.42 \mathrm{~cm}$ and $2365 \mathrm{~kg} / \mathrm{ha}$ respectively at $0.8 \mathrm{IW} / \mathrm{ET}$, with lateral spacing $0.6 \mathrm{~m}$ as compared to other treatments. Highest water use efficiency ( $5.58 \mathrm{~kg} / \mathrm{ha} . \mathrm{mm})$ was observed at $0.6 \mathrm{IW} / \mathrm{ET}_{\mathrm{c}}$ with $0.60 \mathrm{~m}$ lateral spacing. Highest $\mathrm{B}: \mathrm{C}$ ratio (2.27) observed at $0.8 \mathrm{IW} /$ $\mathrm{ET}_{\mathrm{c}}$ with lateral spacing $0.6 \mathrm{~m}$ as compared to other treatments.
\end{abstract}

Key words: Cumin, Drip Irrigation, Irrigation Regimes, Lateral Spacings, Water Use Efficiency.

\section{INTRODUCTION}

India is the largest consumer and producer of cumin in the world. Gujarat is the leading state contributing more than 70 percent in cumin acreage and production followed by Rajasthan It is cultivated in Rabi season in areas receiving low rainfall, and possess well-drained soil, cool-dry and clear climatic condition. Optimum growth temperature ranges between 25 to $30^{\circ} \mathrm{C}^{1}$. Cumin requires low water ${ }^{2,3}$. Some researchers ${ }^{4}$ adopted micro sprinkler irrigation to cumin crop. But in the present environment the authors are not advocating micro sprinkler system due to: (a) requirement of more energy than drip (b) low distribution efficiency due to prevailing wind speeds at later stages of crop growth and deterioration in quality and longevity of the seeds and lastly the reduction in the intensity of the pests and diseases. Drip irrigation reducing energy use, soluble nutrient losses and water, well-aerated condition and enhance water use efficiency due to maintaining high soil matric potential in the root zone. The crop and soil type dictate the lateral spacing and irrigation regimes ${ }^{5,6}$. The research on drip system to cumin ${ }^{3,7,8}$ was mainly focused on plant density, irrigation interval only. The drip irrigation is beneficial only when the system is designed efficiently and irrigation schedules are adopted properly. No work in this direction was progressed. Keeping into cognizance the problems above addressed a study was undertaken to analyze the performance of different irrigation regimes and lateral spacing on morphological and yield attributes of cumin.

\section{MATERIAL AND METHODS}

Experiment was conducted at the instructional farm of Research Training and Testing Centre, Junagadh Agricultural University, Junagadh ( $21^{\circ} 30^{\prime} \mathrm{N}$ latitude and $70^{\circ} 27^{\prime} \mathrm{E}$ longitude) with an 
altitude of $77.5 \mathrm{~m}$ above MSL. Area falls under subtropical and semi-arid with an average annual rainfall of $800-900 \mathrm{~mm}$ and average annual pan evaporation of $5.6 \mathrm{~mm} /$ day. Temperature ranges from $22^{\circ} \mathrm{C}$ to $44^{\circ} \mathrm{C}$ in summer and $10^{\circ} \mathrm{C}$ to $35^{\circ} \mathrm{C}$ in winter. The physicochemical characteristics of the experimental soil are depicted in Table 1. The experiment was undertaken to evaluate three drip irrigation regimes $\left(0.6 \mathrm{IW} / \mathrm{ET}_{\mathrm{c}}, 0.8 \mathrm{IW} / \mathrm{ET}_{\mathrm{c}}\right.$ and $1.0 \mathrm{IW} /$ $\left.\mathrm{ET}_{\mathrm{c}}\right)$ and three lateral spacing $(0.60 \mathrm{~m}, 0.70 \mathrm{~m}$ and $0.80 \mathrm{~m}$ ) on cumin. Split plot design was adopted and treatments were replicated thrice. Integral drip line of $16 \mathrm{~mm}$ diameter at $0.4 \mathrm{~m}$ emitter spacing with discharge of $2 \mathrm{lph}$ (i.e., $5 \mathrm{l} / \mathrm{m} / \mathrm{h}$ ) was adopted based on the study of wetting pattern distribution for different lateral spacing.

Soil was brought to fine tilth by two ploughings with rotavator. Experimental site leveled using plank as shown in plate 3.3. Beds of $2.0 \mathrm{~m} \mathrm{x}$ $7.0 \mathrm{~m}$ size were prepared. Seed treated with thiram @ $3.0 \mathrm{~g} / \mathrm{kg}$. For better germination, it soaked in water for $24 \mathrm{hr}$. It was dried for better broadcasting. 15 metric tonne farm yard manure, $15 \mathrm{~kg}$ Nitrogen and $30 \mathrm{~kg}$ Phosphorus per hectare was given for cumin crop. Cumin variety GC- 4 was grown at rate of 12 $\mathrm{kg} / \mathrm{ha}$ on $22^{\text {nd }}$ November in both experimental years. Average crop duration is 105-110 day. The irrigation withholds after physiological maturity, considering base period about 95 day. Cumin crop is sensitive to wilt disease. Hence, to protect the cumin crop from the attack of pest, insect and fungus disease careful actions were taken as well as possible during crop season. Spraying of thiomethoxam @ $5 \mathrm{~g} / 15$ liter of water was done to control the insect and pest and carbondanzim and mencozab as fungicide were applied. Care was taken to keep crop free from weed. Irrigation frequency was kept as 4 days. The USB evaporation pan was installed in the field to monitor the daily evaporation adjoining to the field. The maximum root zone was observed by agronomists as $60 \mathrm{~cm}$ in the present area. The temporal variation of root depth was determined using the Ferere's et al. (1981) ${ }^{9}$ linear root growth model.

\section{Economics drip irrigation and cumin crop}

Fixed and operating cost considered for economic analysis. Estimation of total production cost, gross revenue and net return for different treatments was done with following assumptions: Cost of drip irrigation system was calculated by the method given by the Dandy and Hassanli (1996) ${ }^{10}$ which is expressed as:

$$
\mathrm{C}=\mathrm{C}_{\mathrm{p}}+\mathrm{C}_{\mathrm{pu}}+\mathrm{C}_{\mathrm{a}}+\mathrm{C}_{\mathrm{i}}+\mathrm{C}_{\mathrm{o}}+\mathrm{C}_{\mathrm{r}}
$$

Where, $C_{p}=$ combined costs of piping. $C_{p u}=$ cost of pump. Cost of accessories is given by $C_{a} \cdot C_{i}=$ installation cost. $C_{0}=$ present value of operating cost of drip computed as per operating hours of pump. $C_{r}$ $=$ present value of repair and maintenance.

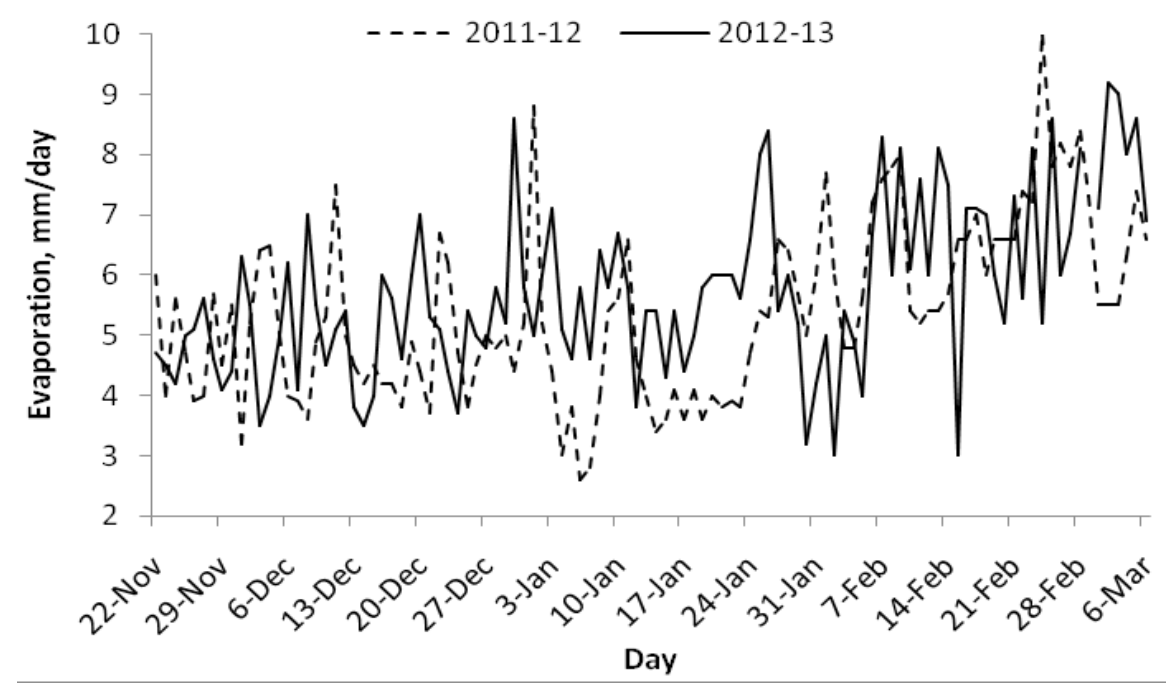

Fig. 1: Daily evaporation of experimental field during year 2011-12 \& 2012-13 
Production cost involved, fixed cost $(\mathrm{F})$ and variable cost (V). Fixed cost includes costs of well, Capital cost, pump, irrigation system and insurance, Interest on capital investment. Variable cost includes costs of inputs, harvesting, and marketing cost of the produce. The return $(R)$ is the monetary value. It is given by benefit $(B)=R$.

\section{Tabel 1: Physio-chemical characteristics of soils}

\begin{tabular}{lcc}
\hline Particulars & Units & Average \\
\hline Bulk density & $\mathrm{g} / \mathrm{cc}$ & 1.44 \\
Specific gravity & $\mathrm{g} / \mathrm{cc}$ & 2.502 \\
Porosity & $\%$ & 49.72 \\
Field capacity & $\%$ & 24.5 \\
Saturation percentage & $\%$ & 45.55 \\
Wilting point & $\%$ & 12.25 \\
Hydraulic conductivity & $\mathrm{cm} / \mathrm{hr}$ & 1.04 \\
ESP(1:2) & $\%$ & 4.5 \\
SAR(1:2) & $\%$ & 0.03 \\
Phosphate & $\mathrm{Kg} / \mathrm{ha}$ & 12 \\
Nitrogen & $\mathrm{Kg} / \mathrm{ha}$ & 210 \\
Potash & $\mathrm{Kg} / \mathrm{ha}$ & 450 \\
PH (1:2.25) & & 8.87 \\
EC ds/m & $\mathrm{ds} / \mathrm{m}$ & 0.20 \\
Sand & $\%$ & 49.78 \\
Silt & $\%$ & 33.68 \\
Clay & $\%$ & 16.52 \\
\hline
\end{tabular}

\section{RESULTS AND DISCUSSIONS}

Impact of irrigation regimes and lateral spacing were analyzed mainly using plant height and yield attributes of cumin, WUE and economics of the system. Daily evaporation during the experimental period for two years is shown in Fig 1. The average evaporation was estimated to be $4.5 \mathrm{~mm} /$ day. The cumulative evaporation during 2011-12 and 201213 was observed to be $570.4 \mathrm{~mm}$ and $603.4 \mathrm{~mm}$. The temperature variation was observed between $13.71^{\circ} \mathrm{C}$ to $30.56^{\circ} \mathrm{C}$ and $14.43^{\circ} \mathrm{C}$ to $31.94^{\circ} \mathrm{C}$ during the experimental year 2011-12 and 2012-13 respectively. The relative humidity was varying from $5 \%$ to $93 \%$ and $5 \%$ to $87 \%$ during the experimental year 2011-12 and 2012-13 respectively.

\section{Plant height and yield attributes}

The combined effect of irrigation regimes and lateral spacings was observed on the plant height, seed yield and dry matter yield of cumin and is depicted in Table 2. The results revealed that there was significant difference in plant height, dry matter yield and seed yield due to interaction effect of irrigation regimes and lateral spacing. Plant height, seed yield and dry matter yield increased with IW/ $\mathrm{ET}_{\mathrm{c}}$ ratio upto 0.8 and declined after that due to oxygen diffusion because of excess water application for the cumin crop for a particular lateral spacing. The same trend prevailed for the remaining lateral spacings. Similarly Plant height decreased with

Table 2: Impact of different treatment combination on cumin morphological parameters

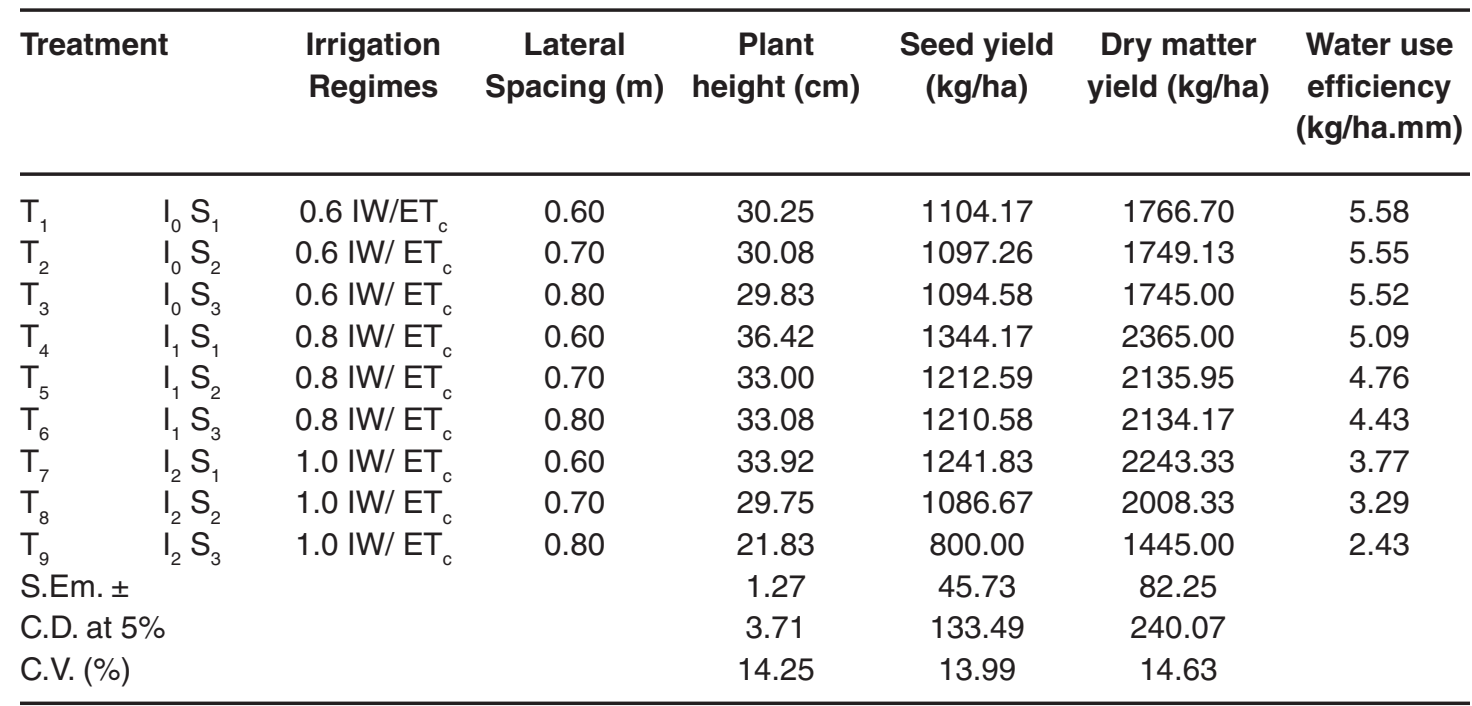


increased lateral spacings for a particular fraction of IW/ETC. This may be due to poor uniformity of water application with increased lateral spacing. The same trend of observations prevailed for other spacings also. Lowest plant height, seed yield and dry matter yield was observed at $0.6 \mathrm{IW} / \mathrm{ET}_{\mathrm{c}}$ due to insufficient availability of water than the required to the crop. Highest plant height $(36.42 \mathrm{~cm})$, seed yield $(1344.17 \mathrm{~kg} / \mathrm{ha})$ and dry matter yield $(2365.00 \mathrm{~kg} / \mathrm{ha})$ were observed at $0.8 \mathrm{IW} / \mathrm{ET}_{\mathrm{c}}$ ratio for $0.60 \mathrm{~m}$ lateral spacings. Highest plant height, seed yield and dry matter yield were observed at a lateral spacing of 0.60 $\mathrm{m}$. Under closer lateral spacing better prevalence of soil moisture, enhanced microbial activity which in turn enhanced the seed yield of cumin. The standard deviation among the replication traits was minimum for all irrigation regimes and lateral spacing. Not only less irrigation water is required with drip, but at the same time yield enhancement is also achieved because of the congenial conditions for better growth is maintained in root zone throughout the crop growth period.

Significant difference was observed in plant height, seed yield and dry matter yield among different treatments during both the years. $\mathrm{T}_{4}$ conceded taller plants, with more dry matter yield and seed yield than the other treatments because water was maintained in the root zone at a level that is congenial for developmental growth of plant. Availability of nutrients in soil during growing season increased growth of plant. An inverse linear relationship between the lateral spacing and plant height, seed yield and dry matter yield were observed.

\section{Water Use Efficiency (WUE)}

WUE is the quantity $(\mathrm{kg})$ of cumin seed production/ ha.mm of water utilized under different treatments. The data on water use efficiency shown in Fig. 1 shows that $I_{0} S_{1}$ gave higher water use efficiency of $5.58 \mathrm{~kg} / \mathrm{ha}-\mathrm{mm}$ than other treatment, lowest water use efficiency of $2.43 \mathrm{~kg} / \mathrm{ha}-\mathrm{mm}$ was found under $\mathrm{I}_{2} \mathrm{~S}_{3}$. The irrigation water productivity was lowest at highest irrigation level and lateral spacings compared to all other treatments in both the years in present experiment. In general, water use efficiency values decreased with increasing water use and lateral spacing. At $0.6 \mathrm{IW} / \mathrm{ET}_{\mathrm{c}}$ and $0.6 \mathrm{~m}$ lateral spacing, uniform water distribution was obtained due of which more water was available in the root zone which might had increased various physiological processes, decreased leaching of water, higher rate of photosynthesis, better plant nutrient uptake, due of which increased seed yield. Treatment $I_{0} S_{1}$ can be suggested for areas with limited water resources.

\section{Economics}

The total cost of cultivation of cumin crop was estimated as summation of the fix costand variable cost and is presented in Table 3 for different irrigation regimes and lateral spacings

Table 3: Economics of cultivation of cumin crop

\begin{tabular}{|c|c|c|c|c|c|c|c|}
\hline & $\begin{array}{l}\text { Seed } \\
\text { Yield } \\
\text { (kg/ha) }\end{array}$ & $\begin{array}{c}\text { Variable } \\
\text { cost } \\
\text { (Rs/ha) }\end{array}$ & $\begin{array}{l}\text { Fixed } \\
\text { cost } \\
\text { (Rs/ha) }\end{array}$ & $\begin{array}{c}\text { TCC } \\
\text { (Rs/ha) }\end{array}$ & $\begin{array}{l}\text { Gross } \\
\text { Income } \\
\text { (Rs/ha) }\end{array}$ & $\begin{array}{c}\text { NR } \\
\text { (Rs/ha) }\end{array}$ & BCR \\
\hline $\mathrm{T}_{1}$ & 1104.46 & 29801 & 35282 & 65083 & 121490 & 56407 & 1.87 \\
\hline $\mathrm{T}_{2}$ & 1097.92 & 29801 & 31301 & 61103 & 120771 & 59668 & 1.98 \\
\hline $\mathrm{T}_{3}$ & 1093.63 & 29801 & 28181 & 57982 & 120299 & 62316 & 2.08 \\
\hline $\mathrm{T}_{4}^{3}$ & 1344.17 & 29801 & 35466 & 65268 & 147858 & 82590 & 2.27 \\
\hline$T_{5}^{4}$ & 1254.37 & 29801 & 31487 & 61288 & 137981 & 76692 & 2.25 \\
\hline $\mathrm{T}_{6}$ & 1168.79 & 29801 & 28368 & 58169 & 128566 & 70397 & 2.21 \\
\hline $\mathrm{T}_{7}^{6}$ & 1241.83 & 29801 & 35137 & 64938 & 136601 & 71662 & 2.11 \\
\hline $\mathrm{T}_{8}$ & 1086.67 & 29801 & 31720 & 61521 & 119533 & 58012 & 1.94 \\
\hline $\mathrm{T}_{9}$ & 800.00 & 29801 & 28602 & 58403 & 88000 & 29596 & 1.51 \\
\hline Control & 650.00 & 58055 & 6750 & 64805 & 71500 & 6694 & 1.10 \\
\hline
\end{tabular}


Gross return was estimated for each treatment considering the prevailing selling price of Rs.110 per kg. The highest net return and benefit cost ratio were found under treatment $0.8 \mathrm{IW} / \mathrm{ET}$. and $0.6 \mathrm{~m}$ lateral spacing due to higher productivity drip irrigation. Cost of system reduced approximately $20 \%$ as lateral spacing increased from $0.6 \mathrm{~m}$ to $0.8 \mathrm{~m}$, but on contrast decreased yield with increase in lateral spacing ultimately affects the $\mathrm{B}: \mathrm{C}$ ratio. The other reason for getting low benefit may be due to poor quality of product under $0.7 \mathrm{~m}$ and $0.8 \mathrm{~m}$ lateral spacing with low water application.

\section{CONCLUSION}

Being an important spice crop and precise water demanding crop water saving methods needs to implement in the cumin. So attempts have been made in the present research work to identify water management strategies in the crop with productive, efficient and economic irrigation systems. Impact of irrigation regimes and lateral spacing on cumin was evaluated in terms of plant height and yield attributes.53.33\% water was saved in $0.8 \mathrm{IW} /$ ETc with highest net return. In other words, one can harvest an equal yield of cumin seed as that of surface method with almost half the amount of irrigation water or one can almost double the area under cumin crop with drip method of irrigation.

\section{REFERENCES}

1. Singh, V.B. and Singh, K. New Age International (P) Limited, New Delhi: 113 (1996).

2. Tavoosi, M. The effect of irrigation regimes on yield and yield components of Cuminum cyminum. M.Sc. thesis. Faculty Agriculture, Ferdowsi University of Mashhad, Iran (2000).

3. Alizadeh, A., Hasheminia, M. \&Tavoosi, M. Water use and plant response to irrigation in cumin. $18^{\text {th }}$ International Congress on Irrigation and Drainage, Montreal, Canada, (pp. 1-6). International Commission on Irrigation and Drainage (ICID) (2002).

4. Awady, M.N., A.M.El-Berry, M.T. El-Tantawy and E.M. Kamal. Evaluation of Growers Sprinkler Irrigation System Management in Bustan Area. The 11th An. Conf. Misr. J. Ag. Eng.:195- 209 (2003).

5. Kang, Y.H. Micro irrigation for the development of sustainable agriculture. Trans. CASE 14 (Suppl.), 251-255 (1998).

6. Keller, J. and Bliesner, R.D. (Eds.). Sprinkle and Trickle Irrigation. Van Nostrand Reinhold, New York, p. 22 (1990).
7. Yadav, R. S. and Dahama, A. K. Effect of planting date, irrigation and weed-control method on yield and water-use efficiency of cumin (Cuminum cyminum L.). Indian journal of agricultural science, 73(9): 494-496 (2003).

8. Akbarinia, A., Khosravifard, M., Sharifi, A. E. and Babakhanlou, P.. Effect of Irrigaton Intervals on Yield and Agronomic Characteristics of Black Cumin (Nigella Sativa). Iranian Journal of Medicinal and Aromatic Plants, 21(1):65-73 (2005).

9. Fereres, E., Goldfien, R. E., Pruit, W. O., Henderson, D. W. and Hagan, R. M. The irrigation management program: $A$ new approach to computer assisted irrigation 23 scheduling. In Proc. Irrigation Scheduling for Water and Energy Conservation in the 80's, ASAE, St. Joseph, Michigan ,USA:202-207 (1981).

10. Dandy, G. and Hassanli, A. . "Optimum Design and Operation of Multiple Subunit Drip Irrigation Systems." J. Irrig. Drain Eng., 10.1061/ (ASCE) 0733-9437(1996)122:5(265), 265275 (1996). 